\title{
UNCONSTITUTIONAL CLAIMS OF MILITARY AUTHORITY ${ }^{1}$
}

The United States remains externally at peace in the midst of a world war, yet within all is not peace. Industrial strife attended with violence and bloodshed has recently given rise to several occasions for the prolonged intervention of the military, notably in Colorado, Montana and West Virginia. The strike of the miners in Colorado, lasting over twelve months, has, by its bitterness and distressing tragedies, attracted the attention of the whole country. Idaho and Pennsylvania have seen similar troubles, and, to a less degree, Ohio, Michigan, New Jersey and Massachusetts. Peace must, of course, be maintained at all hazards, but certain new and extraordinary claims of military authority have been made and acted upon in several of these industrial conflicts, to which careful study and attention ought to be directed.

It is a widespread superstition among military men, and among many other well informed persons, that there is some mysterious and transcendent force in a declaration of martial law. The idea seems to be growing that it is the prerogative and function of the military to substitute itself for all civil authority, and that, while it is in control, the constitutions, courts and laws may be suspended and set aside. ${ }^{2}$

At the time of the great fire which followed the earthquake of April I8, Igo6, at San Francisco, the federal troops were called out by General Funston. A proclamation was issued early on the first day of the fire, which announced that, "The federal troops, the members of the police force, and all special police officers have been authorized to kill any and all persons found engaged in looting, or in the commission of any other crime."

Here we have the assumption of the power of life and death over the citizen.

${ }^{1}$ This article is based upon a paper read at the first annual meeting of the American Society of Military Law, a branch of the American Institute of Criminal Law and Criminology, Washington, D. C., October I9, I9I4.

"See the present writer, "Military Dictatorship in California and West Virginia, I California Law Review, 4I3; E. M. Cullen, Decline of Personal Liberty in America, 48 Am. Law Rev. 345. 
Further illustrations of the assertion of supreme and arbitrary power by federal as well as state military authorities are not far to seek. Recently, in the Colorado strike, the newspapers report that an embargo was put on commerce in arms, and that the transportation of arms and ammunition by any of the railroads or express companies in the state of Colorado was prohibited for any purposes except for the federal troops. It is said that by order of the commander of the federal forces all saloons in certain districts were closed; and that firearms were outlawed and ordered to be surrendered by all citizens under penalty of confiscation. It is further reported that the federal officers in charge in Colorado refused to permit the opening of mines with the aid of strike breakers or non-union men, brought into the district by the coal companies.

One of the most extreme instances of the substitution of military force for law arose in West Virginia during the years IgI2 and I913. Industrial trouble of the gravest character had arisen between the coal miners and coal operators of Paint Creek and Cabin Creek, in Kanawha County, West Virginia. A strike was declared, and non-union labor was brought in to replace the strikers. The coal operators employed "guards" to protect their laborers and their property. The strikers were armed, and machine guns were installed by the operators. September 2, 1912, Governor Glasscock purported to proclaim martial law within a prescribed zone, and appointed a military commission of six officers of the National Guard to try all offenders, except members of the National Guard, and a court martial to try the latter. The first military commission so established is said to have tried and sentenced over one hundred citizens not engaged in the military service of the state, and military commissions later established tried and sentenced scores of other citizens not so engaged. The general orders for the guidance of the West Virginia military commission, in express terms, established it as a substitute for the civil courts. The Governor and military acted under the claim that all the provisions of the constitutions, both state and national, and all the laws and statutes of the state were suspended and for the time inoperative by reason of the existence of martial laze. The proceedings which occurred stirred the lawyers of the Senate to an official inquiry. In the investigation conducted by a Senate Committee of Inquiry, Capt. Morgan, one of the members of the military commission, testified (in answer to a question put by Senator Borah) as follows: 
Q. "Now, then, Capt. Morgan, if the military tribunal of which you were a member had seen fit to sentence a man to the penitentiary for life for perjury, you would have felt that you had the power to do it, would you not?"

A. "Yes, sir; as I viewed it at that time I considered that to be the law."

Colonel Geo. S. Wallace, who acted as judge advocate in these cases, testified:

"My theory of the whole situation was that the governor had a right to declare military law. If he declared military law, then the laws of war applied, and the lazes of war would fix the punishment within the discretion of the military power."

Q. "Then you assumed that the constitution and civil law was suspended?"

A. "I did; and the Supreme Court has sustained that assumption."

Q. "You took the position all the way through this case you have referred to that there was no law within the military zone other than the will of the commander in chief?"

A. "Absolutely; and maintain that yet."

As Colonel Wallace says, the Supreme Court of Appeals of West Virginia has sustained to a great extent the power of the governor to supersede the laws and constitution of the state by military orders and to establish his will as the supreme authority. ${ }^{3}$ In these cases the West Virginia Court, Justice Ira E. Robinson only dissenting, refused to release, on habeas corpus, prisoners held in custody under commitment and sentence or awaiting trial by the military commission. As Robinson, Justice, put the question presented in the Jones case, "May citizens accused of civil offences be tried, sentenced and imprisoned or executed by military commissions at the will of the governor of the state, notwithstanding the civil courts having jurisdiction of the offence are open?"

In the very recent case of Hatfield $v$. Graham, ${ }^{4}$ the West Virginia court reiterated its doctrines. The court grants a writ of prohibition against the exercise of jurisdiction by the trial court

\footnotetext{
${ }^{3}$ State ex rel. Mays v. Brown, 7I W. Va. 527, 77 S. E. 243 ; Ex parte Jones, 7 I W. Va. 609, 77 S. E. ro29.

48 S. E. 533, decided March I3, 19I4. Compare Ulster Sq., Dealer v. Fowler, 58 Misc. (N. Y.) 325 , III N. Y. Supp. I6.
} 
in entertaining a suit for malicious trespass against the governor and certain officers of the militia who acted under the governor's orders and suppressed an issue of a newspaper known as the "Socialist Labor Star." The plant of this paper was at a point in the state remote from the martial law zone. It was charged that an issue of the paper was about to be circulated, antagonizing the governor and encouraging further disorder, and that some copies would be mailed into the district. It was held to be within the governor's power, as commander-in-chief, to suppress the entire issue, to prevent its getting into the mails.

"How about freedom of speech and of the press?" you may well ask. The court concedes that under ordinary conditions of peace the governor could not have lawfully exercised such apparently arbitrary power; but, they said, a condition existed which amounted to domestic war, and called for the exercise of military power of the state to suppress it. The necessity for the act is its justification. As the governor had the discretion to determine whether the necessity therefor existed, the courts have no power to review his discretion or to pronounce his warrant or command unlawful as being in excess of his constitutional power and, if the governor is exempt, this immunity protects his subordinates also. The governor has only to answer that he acts officially, and an action, though alleging that his act is malicious and wholly "without his political province," will be prohibited both as to him and as to his subordinate military officers, whether they act under his written or oral command.

A reign of martial law somewhat similar in its claims to that in West Virginia was inaugurated in Montana during September as result of industrial warfare and dynamiting by strikers in Butte. ${ }^{5}$ On September first, I9I4, Gov. Stewart issued his executive proclamation that Silver Bow County be placed under martial law and under the jurisdiction of the military authorities. Here are parts of a supplementary proclamation by Major Donohue, the commanding officer of the Montana National Guard, as to how Silver Bow County should be governed under military authority:

(5) All saloons and places where intoxicating liquors are sold at retail as a beverage will be closed at once and

\footnotetext{
'The attitude of the Montana Supreme Court toward this reign of martial law will be referred to later. See Ex parte McDonald, in re Gillis, (Igr4) I43 Pac. (Mont.) 947.
} 
kept closed until further order. The stock of liquors of any person or persons violating this rule will be destroyed and all violations severely punished.

(6) Misdemeanors will be punished by the summary court. Maj. Jesse B. Roote is hereby appointed and constituted summary court of the military forces in said Silver Bow County. Violations of state and federal laws, other than misdemeanors, will be referred to a proper military commission for trial and punishment; civil causes will await the ordinary tribunals.

(7) No publication, either in newspaper, pamphlet, hand bill or otherwise, in any way reflecting upon the United States, the state of Montana or their officers, civil or military, or tending to influence the public mind against them, will be tolerated.

(9) All assemblages in streets or highways are forbidden. Assemblages in other places can only be held after the permission of the commanding officer is given.

(Io) Children under I8 years of age will not be permitted on the streets after 7 o'clock p. m., nor before 6 o'clock a. $\mathrm{m}$. Women are requested to not appear on the streets after 8 o'clock p. m., nor before 6 o'clock a. $m$.

(II) Vagrancy will not be tolerated.

(I2) It is hoped that martial law in Silver Bow County will be mild and gentle; but it will be quickly and vigorously exercised when occasion requires.

Given this Ist day of September, I9I4.

DAN J. DONOHUE, Major Commanding.

Official: JESSE B. ROOTE, Major and Adjutant.

Under these proclamations the militia suspended and took over the government of Butte and Silver Bow County and ordered the police court to desist from trying offenders. On September $4^{\text {th }}$ the officer in command of the military force of the state issued orders to the mayor and city council of the city of Butte as follows:

"I hereby permit the full and free operation of all of the several departments of the city of Butte, except that the police court of said city will remain suspended until further orders from me."

On September 3d Major Jesse B. Roote opened a summary military court in Butte without other commission than the proclamation of Major Donohue and proceeded to dispose of the regular police court business. He explained from the bench the status 
of his court in substance as follows:" "The rulings of this court," he said, "are without appeal or review by any power on earth. All powers of the prosecuting attorney and civil officers are suspended during military rule. The military authority may permit such civil officers as it sees fit to continue their duties. The civil courts have, by order of the commander of the militia, been permitted to perform their functions. The military tribunals may prescribe their own rules of procedure, and.while the accused are not entitled to counsel they may have counsel here if they see fit. Military courts may prescribe their own punishments. This court will not be severe. It will not convict anyone except on satisfactory evidence. There will be no bitterness on its part, but the old maxim that 'tyranny is better thann anarchy' applies. There is nothing in the law limiting the punishment that may be inflicted by the court." The orders were that all offences under the penal laws and all acts which would tend to hinder, delay or obstruct the work of the military forces in restoring order should be punishable as offences under martial law, and such punishment should be inflicted as in the judgment of the offcer constituting the summary court should be suitable. ${ }^{7}$

Major Roote proceeded to exercise daily for over a month his multiple functions of major, judge, jury, sheriff, lawgiver and prosecuting attorney. The case of a barber named Waidner furnishes an example of military justice. On September gth Waidner was given sixty days in a military prison for insulting the uniform of the national guard, insulting the flag and the governor of the state and resisting the lawful authorities, how? By refusing to shave a soldier, because he was a militiaman!

Application was made to the federal district court for writs of habeas corpus to release three or four men held as military prisoners. Judge Bourquin refused the application for the writ on the ground of lack of jurisdiction. In an opinion delivered from the bench, however, he is reported to have upheld in sweeping terms the claim that the power of the military is virtually absolute. ${ }^{b}$ His theory is substantially this: If the executive offcers of a court are resisted in the exercise of its processes and decrees, the court is a closed court, even though its doors be open. Thereby the constitution and the statutes are overthrown; for

\footnotetext{
- I have had to rely on the files of the Anaconda Standard, a leading paper of Montana friendly to the mining interests, for the account of the occurrences in Butte.

${ }^{7}$ See Ex parte McDonald, supra.
} 
there is no law where the courts are closed by reason of inability to execute process. While the governor is engaged in maintaining order there are no courts and no civil officers, until restored by the governor. He may restore them one by one, with more or less power, as he proceeds in suppressing the insurrection. His judgment is supreme therein. All statutes and constitutional guarantees are suspended by insurrection. There is no restraint upon the governor but his conscience, his honor and his humanity, except that he may possibly be impeached or held to account later if unreasonably and willfully severe and oppressive. The recitals of fact in his proclamations are conclusive. While the president or governor cannot suspend the writ of habeas corpus, they can suspend the courts. Disturbers inciting to riot may be held in military custody even if the writ of habeas corpus is not suspended.

Under this military form of government Lieutenant Baker was appointed, on September $4^{\text {th }}$, military censor. His jurisdiction embraced the publication and distribution of any and all newspapers and handbills in Silver Bow County. Major Donohue gave a permit for services to be held in Catholic churches in honor of the election of Pope Benedict XV. It was also permitted to ring bells in the churches. The saloons were closed and stocks of liquor were confiscated by the soldiers for selling liquor contrary to military orders. Three men were sentenced to terms of years in the state penitentiary at Deer Lodge and conducted there by a squad of militia under sentence by the military commission for the offence of carrying guns after the institution of martial law.

A prominent attorney who had dared to protest to Senator Walsh by telegraph against the military dictatorship and who had taken the lead in applying for writs of habeas corpus to the federal and state courts on behalf of some military prisoners, was sent for and brought before the military commander by the provost marshal. The gallant commander, having the attorney under his physical power, proceeded to insult and bully him and to denounce his words and actions as contemptible. He was informed that the only reason he was not slapped in jail was because it might glorify him in the eyes of the people as a political martyr.

During the Ohio flood, a company of the Ohio National Guard established a picket line surrounding a portion of the flooded district of the city of Warren, Ohio, a district which had been 
abandoned by the citizens, leaving much property unprotected therein. The picket line was established for the purpose of preventing persons going into that district without a pass. One Smith attempted to pass through the picket line to take some pictures, in defiance of the orders of the soldiery, and was arrested by them. On petition for a habeas corpus the Court of Common Pleas declared that the commanding officer of the militia may make reasonable regulations for the protection of life and property, and the troops may arrest or eject persons attempting to cross guarded lines. ${ }^{8}$ During the San Francisco fire, "fire lines" were maintained by United States soldiers, by which tens of thousands of persons were restricted in their movements and prevented from entering their offices and homes for the purpose of saving their property.

It is reported by Col. H. J. Turney of Cleveland, Ohio, who was on duty at Dayton, that the militia established a military commission, and tried thieves, looters and other criminals, at the time of the Dayton floods. About II7 cases were disposed of, and some of those tried were sentenced to work on the streets under military guard. The employment of military commissions for the summary punishment of strikers has been advocated by reputable persons in Colorado during the recent strike in the coal mining regions of that troubled state.

Coming now to a discussion of the law applicable to these situations, it may help to focus attention on the fundamental issues involved, to formulate some of the principal questions of law that have arisen by reason of the broad claims of military authority recently asserted and acted on in these cases.

I. What is the effect of a proclamation of martial law, and does it suspend the constitution, and the laws of the state and of the United States?

II. Does the governor of a state, by such proclamation, confer on himself, or on his military representatives, a supreme and unlimited power over all his fellow-citizens, within the space described, which suspends the functions of civil courts and magistrates and substitutes in their place the mere will of the military commander?

III. May the military disregard the writ of habeas corpus, or other process of the courts, if issued? Is the writ of habeas corpus in practical effect suspended by such proclamation?

\footnotetext{
sIn re Smith, Cuyahoga Co. Pl., (June I913) 23 Ohio Dec. 667.
} 
IV. May a military commission, or summary courts, be established as a substitute for the ordinary civil courts, to try civilians for (a) felony, (b) misdemeanors, or (c) disobedience of orders and proclamations?

$V$. If so, is there any limit to the punishments which may be prescribed and inflicted? May the military confiscate property and levy fines, as well as imprison and put to death at their discretion?

VI. If they take life, or injure person or property, are the military authorities immune from civil or criminal prosecution for unreasonable acts done in excess of authority? Are the ordinary courts without jurisdiction to inquire into and review the legality of military measures?

VII. May the military shoot persons caught looting, or in the commission of other crimes?

VIII. May the military arrest without warrant, merely on suspicion of complicity in the rioting, or other disturbance?

IX. May the military hold and detain prisoners so arrested on suspicion, for indefinite periods at their discretion, without charge of crime and without turning them over to the civil courts for trial?

$\mathrm{X}$. May the military issue executive orders and proclamations to the citizens generally, having the force of law?

(a) May the military close saloons and confiscate the stock of liquors of those who sell contrary to military orders?

(b) May the military exercise a censorship over the press and suppress newspapers at their discretion?

(c) May the military limit the right or privilege of peaceable public assembly?

(d) May the military prescribe to employers what classes of laborers they shall or shall not employ?

(e) May the military establish "dead lines" within which it is forbidden to civilians to go without a military pass, and so restrict the freedom of movement of peaceable citizens?

(f) May the military confiscate arms, or forbid traffic in arms?

(g) Will a sentry be justified in firing on a person disobeying his orders to halt, where the party is not attempting to carry out any felonious design??

${ }^{\circ}$ Cont. v. Shortall, $206 \mathrm{~Pa}$. St. I65; 65 L. R. A. I93. See the present writer, Martial Law, 12 Columbia Law Rev. 530. 
The affirmative of these questions represents the "Bill of Military Rights" which the supporters of martial law would write across the face of the Bills of Civil Rights of our constitutions. ${ }^{10}$

The extent of military authority can, however, only be ascertained when we have found the source from which it springs. Show us, we will first ask the supporters of military dictatorship, the power to declare this martial law. Can you find it expressed in any provision of the national or state constitutions? If it is not expressed therein but is only to be implied from some of their provisions, show us from which ones. The Federal Constitution makes no mention of martial law. A careful examination of this Constitution makes it clear that no such power was conferred or intended to be conferred, upon any department of the Government, either directly or by necessary implication. ${ }^{11}$

As was pointed out in the famous case of Johnson v. Duncan, ${ }^{12}$ when General Jackson attempted to declare martial law in New Orleans during the War of I8I2, the Constitution of the United States does not provide that in time of public danger the executive power shall reign supreme. It does not trust into the hands of a dictator the reins of government. The framers of the Constitution were too well aware of the hazards of such a provision, and had they made it, the states would have rejected a constitution stained with such a clause.

We are more particularly concerned with the exercise of martial law by the states. The power to declare martial law is expressly recognized only in four states, viz., by the constitutions of Massachusetts, New Hampshire, Rhode Island, and South Carolina, and by three of these it is confined to the legislature. These provisions are contained in their Bills of Rights. By the Massachusetts Declaration of Rights, ${ }^{13}$ "No person can, in any

${ }^{10}$ W. E. Burkhimer, Military Govt. \& Martial Law, (2d ed. 1904) Chaps. 24 and 25; Winthrop, Military Law, 2d ed., pp. I274-1278. State v. Brown, $7 \mathrm{I} \mathrm{W}$. Va. 5I9, 77 S. E. 243 , and notes thereto in $45 \mathrm{I}$. R. A. (N. S.) 996 , and in Ann. Cas. ror4 C., p. I; Ex parte Jones, $7 \mathrm{I}$ W. Va. 567, 77 S. E. 1029, 45 L. R. A. (N. S.) 1030; Ex parte Field, 9 Fed. Cas. I; Hatfield v. Graham, 8r S. E. (W. Va.) 533; Re Boyle, 6 Idaho 609, 45 L. R. A. 832 ; Re Moyer, (see note 18) 35 Colo. 159, 85 Pac. 190; Com. v. Shortall, supra.

${ }^{11}$ See G. B. Davis, Military Law, p. 305.

${ }^{13} 3$ Mart O. S. (La.) 530, 6 Am. Dec. 675; 2 Hare, Am. Const. Law, Chap. 44.

${ }^{13}$ Part I, Art. 28. I am indebted to Dr. Blaine F. Moore for assistance in examining the various state constitutions. 
case, be subject to law-martial, or to any penalties or pains by virtue of that law, except those employed in the army or navy, and except the militia in active service, but by authority of the legislature." The provisions of New Hampshire and South Carolina are the same. ${ }^{14}$ By the Rhode Island Declaration of Rights, ${ }^{15}$ "the military shall be held in strict subordination to the civil authorities. And the law-martial shall be used and exercised, in such cases only, as occasion shall necessarily require."

It is to be observed that these provisions of the respective Bills of Rights of these four states are intended as limitations and not as grants of power. What the proper construction of the term "law-martial" as there employed is, it is impossible to say. It is further to be remembered that every article in the Declaration of Rights, as well as the constitution of a state, is subject to the paramount control of the Constitution of the United States, which annuls and destroys every thing irreconcilable with it. ${ }^{16}$ The power of the legislature of a state to declare martial law, in the strict sense, is doubtless forbidden by the Fourteenth Amendment to the Federal Constitution, requiring due process of law. Martial law in the sense of the unrestricted power of military officers, or others, to dispose of the persons, liberties or property of the citizen, is in Tennessee, declared inconsistent with the principles of a free government, and is not confided to any department of the state government. ${ }^{17}$ The constitutions of at least twenty states declare that laws can be suspended only by the legislature. By express declaration in several states no person can be subjected to martial law or to punishment thereby except those in the army, navy or militia in actual service. ${ }^{18}$

The only express grant of power to the executive to declare martial law is contained in the constitution of the Territory of Hawaii. This is derived from Article $3^{\mathrm{I}}$ of the Constitution of the Republic of Hawaii which provided that the president might, in case of rebellion or invasion, or imminent danger thereof when the public safety requires it, suspend the writ of habeas corpus, or place the whole or any part of the republic under martial law. Under this provision, it was held that the executive

${ }^{14}$ N. H. Part. I, Art. 34; S. C. Art. I, Sec. 27.

${ }^{13}$ Art. I, Sec. I8.

${ }^{18}$ Jones v. Crittenden, 6 Am. Dec. (N. C.) 531.

${ }^{17}$ Tenn. I, 25.

${ }^{18}$ Md., Me., Vt., W. Va., Tenn. See Stimson, Federal and State Constitutions, Sec. 126, 293. 
alone has discretion to decide whether the exigency is such as to require martial law, how long it is to continue in force, and that the measures taken by the military authorities, such as trial by a military commission, could not be inquired into or reviewed by the courts. ${ }^{19}$ The trial of a citizen for treason by a military court was accordingly sustained, although the civil courts were in session. If such a discretionary power is derived from the constitution, it seems that it is ipso facto withdrawn from legislative or judicial regulation, as no department has the right to interfere with powers conferred upon another which carry or imply any discretion. ${ }^{20}$

The governor may by the constitution of most states call out the militia to execute the laws, suppress insurrection and repel invasion. ${ }^{21}$ In the absence of a direct grant of power, the governor's authority to inaugurate or proclaim martial law finds a constitutional sanction, according to the ingenious court of West Virginia, as implied in or incidental to this power, in the exercise of which it is claimed he has absolute political discretion as to the means to make it effective. There is no objection to allowing the governor entire discretion as to the occasion for calling out the troops, or as to the necessity for keeping them on duty. But the use of the military is another matter. Military officers do not have unlimited discretion as to the means and measures which may be employed to restore peace. These are defined by law, as is the exercise of force in private self-defence. It is necessary to distinguish between the use of military power in aid of the civil authorities, and martial law in the technical sense. In the one case, the law governs; in the other, military force. In the one, military power is the servant of the law; in the other, it is the master. ${ }^{22}$ Does the provision for a militia and for its use in keeping the peace and executing the law annihilate, by mere implication and presumption, other express provisions of the constitution?

The military is in all states, except New York, declared forever subordinate to the civil power. ${ }^{23}$ As it is put in the

${ }^{19}$ In re Kalanianaole, (1895) Io Hawaii Rep. 29.

${ }^{20}$ See State v. Dickerson, 33 Nev. II3, II3 Pac. I05I; Barcelon v. Baker, 5 Philippine Rep. 87.

${ }^{21}$ Stimson Federal and State Constitutions, p. 247.

22 See the argument of David Dudley Field in behalf of William McCardle, in Sup. Ct. U. S. I868, Veeder's Legal Masterpieces, p. 969.

${ }^{23}$ Stimson, Federal and State Constitutions, p. 245, Sec. 292. 
Massachusetts Declaration of Rights, Article I7, "And the military power shall always be held in exact subordination to the civil power, and be governed by it." The courts have had some difficulty with the proper construction of this provision. It has been supposed by some that this means that the military can only act under the order of the civil peace officers, and in aid of sheriffs and other magistrates. ${ }^{24}$ But it would seem that this provision could not have been intended merely to restrict the military to acting under the orders of some civil peace officer, such as a mayor or sheriff. In a noted Colorado case, ${ }^{25}$ it was held that the governor, acting through the militia, might seize and detain suspects without turning them over to the civil courts until the insurrection was suppressed. It was said that this did not violate the constitutional provision that the militia shall always be in strict subordination to the civil power, since the governor acts in his civil capacity. Thus the clause was allowed to have no restraining effect. But as Steele, J., points out in his able dissenting opinion, Does this provision have no meaning except that the military shall always be under the command of the governor? That is simply annulling this section of the Bill of Rights. The provision must have some meaning. It can have no meaning if construed as it is by the majority of the Colorado court. Such a method of construction cannot but be regarded as disingenuous. It is a form of juggling which makes of our constitutions "mere scraps of paper."

The "military authorities" of a state can only be the governor and his military representatives in command of its armed forces. The "civil authorities" include not only the sheriff, police, and the ordinary peace officers, but also the courts of law to which they are subordinate. By civil power or authority must in general be understood the ordinary law, as declared by the courts of law. This provision is a declaration of the supremacy of law as against arbitrary, executive discretion. ${ }^{26}$

Martial law, which destroys constitutional guaranties and supersedes the law and the courts, renders the "military inde-

${ }^{21}$ Ela v. Smith, 5 Gray (Mass.) I2I (1855); State v. Coit, 8 Ohio Dec. 62 (I897).

In In re Moyer, 35 Colo. I59, 85 Pac. 190, 12 L. R. A. (N. S.) 979.

${ }^{20}$ "Soldiers and citizens alike stand under the law. Both must obey its commands and be responsible to its courts." Fluke v. Canton, 31 Okla. 718, 123 Pac. I049 (I912) ; Franks v. Smith, I42 Ky. 232, I34 S. W. 484, Ann. Cas. Igr2 D 319; Christian Connty v. Merrigan, I9r I1l. 484, 6r N. E. 479. 
pendent of and superior to the civil power," the attempt to do which by the king of Great Britain was deemed by our fathers such an offense that they assigned it to the world as one of the causes which impelled them to declare their independence. ${ }^{27}$ Yet, in the Colorado, West Virginia and Idaho cases this clause as to the subordination of the military power has had no restraining effect, and has either been misinterpreted, discarded, or ignored. The military has been made largely independent of the courts and the courts have been content to abdicate the supremacy of law and civil authority.

The whole history of English constitutional development shows a dramatic and successful struggle for the complete subordination of executive power to law. In American constitutional law, a tendency appears to restrict the sphere of law, both in favor of property rights and contracts as against legislative power and also in favor of the independence of executive power as against personal liberty.

The argument for the power of the governor to proclaim martial law, create a military commission, try and sentence civilians, and award such punishment as he may deem fit and proper, was further rested by the West Virginia court on still another ground: That this power is a power of self-preservation, which is a necessary incident or attribute of sovereignty and belongs in England to the Crown. The necessity for exercising this power, which must be lodged somewhere, is determinable by the governor of the state and his decision is not reviewable in any manner by the courts. In order to test this prerogative theory it is necessary to consider the situation under the English constitution and the common law system from which it purports to be derived.

Considerable controversy exists between English writers on constitutional and military law, as to whether any power to proclaim martial law really exists as a prerogative of the Crown, or whether the use of military force does not depend on the common law privilege and duty of all, ruler and citizen alike, to use any force necessary to overcome violence and suppress disorder. In the Case of Ship Money, ${ }^{28}$ "the opinion of a majority of the judges was in favor of allowing the Crown a power to proclaim martial law, whenever the country was in danger; and of

${ }^{27}$ Ex parte Milligan, 4 Wall. (U. S.) 2.

${ }^{\approx 8}$ State Trials, 826 (1637). 
the existence of that danger they held that the Crown was the sole judge. "It was clear, however, from the Petition of Right (1627, 3 Car. I) that the actual decision in the Case of Ship Money was wrong. It is the views of the lawyers who framed the Petition of Right, and who argued the Case of Ship Money for Hampden, which have prevailed."29

Finlason, an English lawyer, who has written several works on this subject, supports the military view that the Crown once had a prerogative to govern ordinary citizens by martial law in case of rebellion which amounted to a war, and that this prerogative still remains. ${ }^{30}$ This power can, of course, be exercised, even according to these writers, only if a state of war as defined by law really exists. Their contention only goes to this extent, that the Petition of Right is simply aimed at martial law in time of peace, and that rebellion, when the courts are closed, is a state of public war within the realm. Thus a proclamation of martial law in England would be a declaration of a state of war. This theory seems to have been adopted by a case which arose during the Boer War in South Africa, that when a state of rebellion amounting to war exists, the courts have no authority or jurisdiction to call in question the measures of the military authority. ${ }^{31}$ This case, however, rejected the ancient test of Coke, Rolle and $\mathrm{Hale}^{32}$ that when the courts are open it is time of peace, and treated the determination or proclamation of the military as conclusive as to when a state of war will be deemed to exist. The denial of the jurisdiction of the courts by this case has been severely criticised. ${ }^{33}$

The better opinion would seem to be that the power to proclaim martial law is not a part of the English constitution or common

\footnotetext{
${ }^{20}$ Holdsworth, Martial Law Historically Considered, I8 Law Quar. Rev. I24, I3I; G. G. Phillimore, Jour. Soc. Comp. Leg. (I900) vol. 2 N. S. p. 5r.

${ }^{30}$ Finlason, Treatise on Martial Law; Commentaries on Martial Law; Review of Authorities as to Repression of Riots and Rebellion. See also Forsyth, Cases \& Opinions on Constitutional Law, pp. I98, I99, 553, 556, 557.

${ }^{3}$ Ex parte Marais, (I902) A. C. I09.

${ }^{32}$ I Hale, P. C. 344; Hist. Common Law, p. 42, 43; Rushworth Historical Collections, Vol. II, Appendix, pp. 79, 8r.

${ }^{33}$ Edinburgh Review, Jan. 1902, Vol. 195, p. 79. See also Dicey, Law of Constitution, pp. 7th ed. 283, 288, 545; Sir F. Pollock, I8 Law Quar. Rev. I52; I2 Columbia Law Rev. 536; Cyril Dodd, The Case of Marais, I8 L. Q. R. I43, I48; and the present writer.
} 
law. ${ }^{34}$ Professor Dicey contends that martial law does not apply in England even to rebels, and cites Wolfe Tone's case as illustrating the noble energy with which the judges have maintained the rule of regular law, even at periods of revolutionary violence. Certainly, it has never been clearly recognized or established. Every proclamation of martial law, either in the United Kingdom or the colonies, has been followed by an Act of Indemnity. These acts are always so framed as to protect only such measures and proceedings as have been done bona fide and of necessity to meet the emergency. ${ }^{35}$ This is evidently on the ground that the existence of any such prerogative is either denied or doubted, and that it is necessary to protect persons who have acted bona fide in time of war or insurrection by a special retroactive statute.

It would seem evident that to uphold the declaration of martial law as a war measure, as certain English writers do, excludes the power from the states. It is, accordingly, necessary for the West Virginia court to go to the extreme of recognizing an alleged war power in the various states; and the court holds that the governor of a state may, like the king of England, declare martial law during a time of insurrection by virtue of the sovereign war power of the state. The West Virginia court thus puts its theory: "The declaration of a state of war was, in law and in fact, a recognition or establishment of a state of belligerency, and made the inhabitants of the military district technically enemies of the state." ${ }^{\text {36 }}$ But the learned court thus fails to observe the distinction between the kind of military authority which may be exercised by the federal government over enemy territory in war and that exercised by a state in putting down riot within its own borders. Insurrection and war are not convertible terms, and calling mob violence and persistent rioting and disorder by the name of "rebellion" does not reduce citizens to the status of public enemies. ${ }^{37}$

As was pointed out by Justice Woodbury in his learned and elaborate dissenting opinion in the case of Luther $v$. Borden, ${ }^{38}$

${ }^{34}$ See Phillimore, Journ. Soc. Comp. Legis. Vol. 2, N. S. p. 5I; Grant v. Gould, (1792) 2 H. B1. 69, 98; Blackburn, J., in R. v. Eyre, (I868) Finlason's Report at p. 74; R. v. Nelson \& Brand, (1867) Frederick Cockburn's Report, 59 .

${ }^{35}$ I95 Edinburgh Review, p. 90.

"State v. Brown, supra.

"See Alleghany Co. v. Gibson, 90 Pa. St. 397, 417; The Prize Cases, 2 Black. (U. S.) 635, 673, I7 L. Ed. 459

${ }^{38} 7$ How. (U. S.) $7 \mathrm{r}$. 
domestic violence is to be regarded, not as a state of war giving belligerent rights, but as conferring only the powers of peace on the state. These are to be exercised through its civil authorities, aided by its militia, until the general Government interferes and recognizes the contest as a war. The Constitution expressly provides that "The Congress shall have power to declare war." To remove all doubt on the exclusiveness of the war power in Congress in all cases, domestic or foreign, there is a prohibition on the states that "No state shall, without the consent of Congress, engage in war unless actually invaded, or in such imminent danger as will not admit of delay." ${ }^{40}$ This manifestly refers to danger from a foreign enemy threatening invasion, which is always used as contrasted with domestic insurrection. ${ }^{41}$ A state of the Union, therefore, has no constitutional power to go to war, either with itself or with other states, or to give to its citizens the status of public enemies with no rights which the military are bound to respect. The maxim, Inter arma silent leges, does not apply in a state, and authorities as to military government which may be exercised by an invading general over the inhabitants of enemy territory during a public war (such as that exercised in the South in the War of the Rebellion) do not apply. Martial law exercised by a state or by the United States on the request of the state, in putting down domestic riot and disorder among its own citizens must be supported, if at all, on some basis entirely different from military government, which can only be exercised in time of war and by the United States. ${ }^{42}$

In the case of military occupation of enemy territory the president and his officers have an absolutely free hand. As it is clearly explained by Mr. Cushing, in an opinion which he gave when attorney-general, "This is incidental to the state of solemn war, and appertains to the law of nations. The commander of an invading, occupying or conquering army rules the invaded country with supreme power, limited only by international law and the orders of the sovereign or government he serves or represents. . . . . This does not enlighten us as to martial law in one's own country, and as administered by its own military

Art. I, Sec. 8.

* Art. I, Sec. Io.

"Luther v. Borden, 7 How. (U. S.) 7I-73.

See Col. H. C. Caraugh, Martial Law, 7 Ill. Law Review 479, 495; Winter $v$. Dickerman, ( 1868 ) 42 Ala. 92, a case relating to military occupation during the Civil War. 
commanders. This is a case which the law of nations does not reach." ${ }^{43}$

Accordingly, the oft-quoted doctrine that martial law may prevail when the courts are closed and not able to administer justice, as this is a state of war, does not apply to the states even if it be sound as to the United States. It cannot, therefore, be claimed that the governor has power to establish a military commission as incident to his power to declare a state of war. The language of Taney, C. J., in Luther v. Borden, used arguendo, that the supreme court could not question the authority of the state legislature to declare martial law during Dorr's Rebellion, as it was a state of war in which the state might resort to the rights and usages of war, is very unfortunate and misleading, although made much of by some courts and military writers.44 As Luther $v$. Borden was decided in 1842 , before the adoption of the Fourteenth Amendment, there was at that time no ground upon which the supreme court could review or interfere with the action of the state legislature. This case, therefore, is no authority in favor of martial law. ${ }^{45}$ As was said by Mr. W. J. Mathews, President of the West Virginia Bar Association, in an able address delivered at its twenty-ninth annual session in I9I3, commenting upon the West Virginia cases, "The argument that the right to exercise such a power is so inherent in the state and so sovereign in its character as to raise a well-nigh conclusive presumption that the people themselves, in forming their own organic law, for their own self-government, did not selfimpose restrictions upon its exercise by the executive, is a plain confusion of the power of the people as a whole with the power they saw fit to confer upon the executive." It would seem manifest that the power of the governor extends to the enforcement of the constitution and law of the state only, not to the suspension of such laws, or the substitution for them of arbitrary rules and orders under pretence of "executing" them.

\footnotetext{
- VIII, Opinions of Atty. General, at p. 369.

4t This is properly criticised and the true doctrine stated in 2 Willoughby on the Constitution, p. I238.

${ }^{2}$ Despan v. Olney, 7 Fed. Cas. No. 3822, p. 534, another Dorr case, though decided in 1852 , which cites Luther $v$. Borden as holding that the legislature of a state may declare martial law, is open to the same observations, as also to the criticism that in neither of these cases was there any necessity of going much further than to uphold ordinary common law rights of arrest without warrant.
} 
It has been supposed by some that the power to declare martial law is connected with the power to suspend the writ of habeas corpus. By the constitutions of most states this writ can only be suspended when, in cases of invasion or rebellion, the public safety requires it. By the constitutions of several states the writ can never be suspended in any case. The constitutions of several states provide that the writ can only be suspended by the legislature, and in other states this is implied by the due process of law clause.48 "It has been the settled law of this country ever since 1807 that the suspension of the writ of habeas corpus is a legislative and not an executive function. If, therefore, the power to suspend that writ must stand or fall with the power to establish absolute martial law, the inference is inevitable that no such régime can be established by the executive. ${ }^{47}$

It has been suggested that the practical object of suspending the writ of habeas corpus is to permit and authorize the arbitrary arrest and imprisonment of persons against whom no legal crime can be proved. As was said by Judge Deady, in the case of McCall v. McDowell et al.,48 "Plainly expressed, the suspension of the privilege of the writ is an express permission and direction from Congress to the executive to arrest and imprison all persons for the time being whom he has reason to believe or suspect of intention or conduct in relation to the rebellion or invasion which may be injurious to the common weal. . . . . If the suspension of the privilege of the writ is not intended to authorize and permit arrests without ordinary cause or warrant, for what is it intended?"

This idea is, however, repudiated by Mr. Justice Davis, in Ex parte Milligan.49 "The suspension of the writ does not authorize the arrest of any one, but simply denies to the arrested the privilege of the writ in order to obtain his liberty." It merely enables the government to detain a prisoner arrested for good cause for an indefinite time, without trial or bail. It does not legalize seizures otherwise arbitrary. No charter for undefined and unlimited authority even in the legislature can be found here. All other remedies for illegal arrest remain and may be pursued against the parties making or continuing them. The

* Stimson, Fed. \& State Const. p. I27.

${ }^{" E x}$ parte McDonald, I43 Pac. (Mont. I914) 947, 951.

I Abb. (U. S.) 212, I5 Fed. Cas. p. 1235, Case No. 8673.

${ }^{4} 4$ Wall. 2, Ir5. 
suspension of the writ of habeas corpus is therefore wholly unlike and falls far short of martial law. ${ }^{50}$

It has been held, however, by the Supreme Court of Colorado in the Moyer case ${ }^{51}$ that, entirely independent of the authority of the governor to declare martial law, or to suspend the writ of habeas corpus, any person may lawfully be arrested by the military authorities on suspicion of participating in, or aiding or abetting an insurrection, and the legality of the arrest and detention cannot be inquired into or reviewed by the courts. It is argued that if offenders or suspects must be handed over to the civil courts they might be released on bail, and left free to rejoin the rioters. Further, the military might be subjected to actions of replevin by those whom they had deprived of their arms, and might be required to return them to those who would thus be equipped to continue their lawless conduct. It is further held that the courts cannot review the facts upon which the governor acted, in arresting suspects, as this would be a direct interference with his authority. The court argues that, since the military may resort to the extreme measure of taking life in order to suppress insurrection, the milder means of seizing and imprisoning the persons participating in riot must $a$ fortiori be justifiable.

Does the Colorado court then mean to contend that the military may execute and put to death any person merely on suspicion? As Steele, J., points out in his able dissenting opinion, the power to resist or arrest rioters engaged in the open disturbance of the peace is a very different matter from a power to arrest any one whom the military accuse or suspect of possible participation in such disturbances. It is a matter for amazement that courts should acquiesce in the claim that any citizen may be arrested at the mere pleasure of these military policemen, and confined in a prison cell for many months, at their discretion without remedy. ${ }^{52}$ If they are to hold prisoners until order is restored, what assurance or limit is there on the length of time a man may be held? Yet the Colorado court decides that persons so arrested by the military on suspicion only may be

${ }^{50}$ Luther v. Borden, 7 How. I, 60; Griffin v. Wilcox, 2I Ind. 370; Pomeroy, Constitutional Law, Sec. 708-7I4; 2 Willoughby, On the Constitution, Ch. 62, p. 1247; Cooley, Principles of Constitutional Law, p. 289; G. B. Davis, Military Law, p. 332 .

${ }^{51}$ In re Moyer, 35 Colo. 159, I2 L. R. A. (N. S.) 979, II7 Am. St. Rep. I89.

${ }^{32}$ See Skeen v. Monkheimer, 2I Ind. 1. Jones v. Seward, 40 Barb. (N. Y.) 563 (1863); Ex parte Moore, 64 N. C. $802,807$. 
restrained of their liberty, without warrant or charge, until such time as the governor declares the insurrection to be at an end and order to be restored.

The Supreme Court of the United States has unfortunately lent apparent countenance to this doctrine. Chas. W. Moyer sued former Governor Peabody of Colorado for false imprisonment without due process of law at the hands of the militia acting under the Governor's orders. He was not arrested as a rioter taken in the act, but merely on suspicion, and was detained, it was alleged, for over two months without probable cause and without any attempt to bring him before the courts or prefer a charge of crime. The Federal Circuit Court sustained a demurrer to the complaint, and the Supreme Court affirmed the decision on the ground that the allegations did not show that he had been deprived of his liberty without due process of law. ${ }^{\text {s3 }}$ Mr. Justice Holmes says in his opinion: "So long as such arrests are made in good faith or the honest belief that they are needed to head insurrection off, the governor is the final judge; and he cannot be subjected to an action after he is out of office on the ground that he had no reasonable ground for his belief."

The Supreme Court thus holds that as far as the Fourteenth Amendment is concerned, a wanton abuse of power must be alleged, and that the discretion of the commander is limited only by good faith. He cannot be compelled to show reasonable and probable ground for believing in the necessity of the detention. This doctrine is at least consistent with the nominal supremacy of the law and civil courts, although the language used does not seem as carefully weighed as one would expect from the learned Justice of the Court.54 There is of course a great difference between what the law may be under the Constitution, and what it is or ought to be.

If, as the Colorado court says, the grounds and legality of the imprisonment of persons arrested without warrant, or otherwise, cannot be inquired into by the courts, and if the governor is the sole judge of the necessity to imprison and detain suspects, then the writ of habeas corpus is certainly suspended, for all practical purposes..$^{55}$ When an insurrection is prolonged, as in Colorado, such a doctrine may result in the indefinite detention

${ }^{2}$ Moyer v. Peabody, 148 Fed. 870; affirmed 212 U. S. 78, 53 L. Ed. 4 IO.

sI II Willoughby, Const. Law, p. I24I.

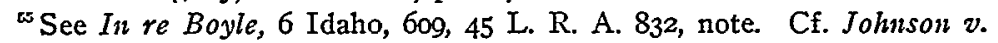
Jones, 44 IIl. I56, $92 \mathrm{Am}$. Dec. I59. 
of military prisoners. This is a form of punishment and the summary trial and punishment of offenders by military commission might be preferable to such detention. The Montana court, while it professes to follow this Colorado doctrine, shows a disposition to limit it, and to inquire from time to time into the necessity of the detention. ${ }^{47}$ It would seem that military prisoners should be turned over to the civil authorities for trial, as soon as that could be safely done, to wit, when danger of rescue is over; and that the courts should at least inquire into the facts as to the good faith and necessity of the detention.

If not martial law, then what? it may be asked. One who supposes that the ordinary law is helpless in the face of violence, disorder, and public danger shows himself very ignorant of the authority and resources which the law affords. Before we throw constitutional liberty overboard, even for a day, let it be clearly proved that the resources of the common and statutory law are inadequate. It will be found that the government has within the constitution all the powers which are necessary to preserve its existence and that of society. The strong arm of the Federal Government is behind the state governments by express constitutional mandate to insure them a republican form of government, and to protect them from domestic violence too strong to be overcome by local authority. This is not a war power, but a peace power.

The orthodox common law doctrine as to the source and scope of the powers of the military may be termed that of public self defense or police power. ${ }^{5 B}$ According to this doctrine the military is merely an extension of the police force of the state for the restoration of public order. Thus the intervention of the military does not introduce martial law.

As was said by Tindall, C. J., in charging a grand jury on the occasion of the Bristol riots," "The law of England hath, in proportion to the danger which it attaches to riotous and dis-

${ }^{88}$ Franks ข. Smith, I42 Ky. 232, I34 S. W. 484, Ann. Cas. I9I2 D, p. 3r9; Ela v. Smith, 5 Gray (Mass.) I2I, 66 Am. Dec. 356; Fluke v. Canton, 3I Okla. 7I8, I23 Pac. Rep. 1054. See also authorities collected in dissenting opinions by Robinson J., State v. Brown, 77 S. E. 255, 256; Ex parte Jones, 77 S. E. I053. See also, Stephen, History of the Criminal Law, v. I, page 2I4; W. H. Moore, Act of State in English Law, p. 48; Dicey, Law of the Const., 7 th ed. 538; 2 Hare, Am. Const. Law, p. 906. Willoughby, Const. Law, I24I ; I2 Columbia Law Rev. 529.

${ }^{87} 3$ State Trials, N. S. I, 5 C. \& P. 254, 261. 
orderly meetings, made ample provision for preventing such offenses, and for the prompt and effectual suppression of them whenever they arise."

Lord Mansfield, the great expounder of the common law, in an impressive speech on the employment of the military to quell the Lord George Gordon riots of 1780 , denied before Parliament that this proceeded from any extraordinary exertion of the royal prerogative, or that it could only be justified by proclamation of martial law. "Every individual," he said, "in his private capacity, may lawfully interfere to suppress a riot, much more to prevent acts of felony, treason, and rebellion. . . . . . What any individual may lawfully do for the prevention of crime and the preservation of the public peace may be done by any number assembled to perform their duties as good citizens. It is the peculiar business of all constables to apprehend rioters, to endeavor to disperse all unlawful assemblies, and, in case of resistance, to attack, to wound, nay, kill, those who continue to resist;-taking care not to commit unnecessary violence or to abuse the power legally vested in them. . . . . The persons who assisted in the suppression of these tumults are to be considered as mere private individuals acting as duty required. My lords, we have not been living under martial law, but under that law which it has long been my sacred function to administer. . . . . . Supposing a soldier, or any other military person who acted in the course of the late riots, had exceeded the powers with which he was invested, I have not a single doubt that he may be punished, not by court-martial but upon an indictment."

"Consequently the idea is false that we are living under a military government, or that, since the commencement of the riots, any part of the laws of the Constitution has been suspended or dispensed with. . . . . The military have been called in, not as soldiers, but as citizens. They were employed (no matter whether their coats were red or brown) not to subvert, but to preserve the laws and Constitution which we all prize so highly." 58

At common law the powers of peace officers are in general restricted to the following things:

(I) To making arrests with, and in some cases without warrant, and overcoming resistance thereto.

${ }^{\text {ss }} 3$ Campbell, Lives of the Chief Justices 4I5, 2I Part. Hist. 688-698. 
(2) To resisting felonious outrages and all breaches of the peace and repressing violence.

(3) To dispersing riots, routs, and unlawful assemblies, and clearing the streets.

The powers of the military, coming to the aid of civil authorities, would seem in general to be limited to what peace officers may do, unless valid statutes give them additional powers. At common law a peace officer could not arrest any one merely because suspected of being a leader or instigator of disturbances, or of being guilty of any other misdemeanor. American common law, however, seems disposed to grant this authority to the military, and to go to the extent of holding that the exercise of the police power justifies not only the arrest but also the temporary, provisional, preventive detention of dangerous characters during an insurrection. The courts of some states will refuse to release such prisoners on habeas corpus. If this power is to be recognized, it is the courts who are to control it, and inquire from time to time into the facts. We pride ourselves in America on being governed by law; yet there is scarcely a country in Europe in which more independent discretionary power is claimed by virtue of executive authority than here.

There is, however, a sharp distinction between the power of a policeman to arrest and the power of a policeman to constitute himself a court or legislature and try and convict, sentence and execute offenders for violations of law or of his own orders. The governor or militia have no more power to do this than any ordinary police officer, and against the assumption and assertion of such power we should record an emphatic protest. The power of the executive to arrest and detain rioters taken in the act, and also those suspected of criminally inciting to riot and violence, until they may be turned over to the civil courts, is merely an extension of the executive powers of ordinary peace officers; but the power to try and punish is a judicial, not an executive, power.

As a matter of common law, therefore, the powers of the military would seem to be preventive, defensive, and ministerial, with no authority to issue orders to citizens generally, or to punish those who disobey commands or commit offenses. Under the ordinary law which at all times prevails, property may be destroyed to prevent the spreading of fire or of pestilence, and public danger will justify the impressing of private property into public service in cases of actual or apparent necessity. The 
maxim Salus Populi Suprema Lex, that the good of the individual must yield to the public safety, gives liberal scope to the common law justification of necessity. The common law doctrine, while it admits that extraordinary occasions may require extraordinary measures, yet insists that measures for public safety be limited by the reasonable necessities of the case, even in time of war..$^{50}$

It has been suggested by Sir Frederick Pollock that so-called martial law is "the justification by the common law of acts done by necessity for the defense of the commonwealth when there is war in the realm." He suggests that trespasses should be justifiable, when they are "acts which any prudent and courageous " magistrate would certainly do under the circumstances," and that "the existence of reasonable and probable cause for the act complained of, having regard to the public danger, is necessary and sufficient to justify it." Juries, he says, are not likely to take an unduly narrow view of what a man may reasonably do in the public interest on such an occasion. But any abuse of power on the pretext of public need for ends of private malice should be severely dealt with. The ordinary courts have at all times jurisdiction to review and regulate military measures, and good faith alone is not a sufficient justification. ${ }^{60}$

It may be that we should expand somewhat by statute the common law justification of necessity and public self-defense and of the authority of peace officers in these cases. If our laws are defective in regulating the use and possession of fire arms, or of the occasions on which saloons should be closed, they should be amended and statutes should be enacted to cover possible emergencies. The laws should be supplemented by the arbitrary orders of executive officers.

The Montana Supreme Court in its recent decision ${ }^{61}$ repudiated the claim that the civil courts are without jurisdiction to order the release of a prisoner held by the militia after declaration of martial law. The Court further held that neither the governor nor the military under him can lawfully punish for

\footnotetext{
${ }^{60}$ Case of the King's Prerogative in Saltpetre, I2 Rep. 12; Monse's Case, 12 Rep. 63; Conn. v. Palmer, 2 Bush (Ky.) 57o; Corbin v. Marsh, 2 Duv. (Ky.) I93; Mitchell v. Harmony, I3 How. (U. S.) II5, I4 L. ed. 75; W. H. Moore, Act of State in English Law, p. 48; I2 Col. Law Rev. 529.

${ }^{c}$ F. Pollock, What is Martial Law? I8 Law Quar. Rev. 152.

${ }^{\text {a }}$ Ex parte McDonald, supra.
} 
insurrection or for other violations of the law. The courts can not be ousted by the agencies detailed to aid them, nor can their functions be transferred to tribunals unknown to the Constitution. The argument that the weakness of civil courts and officers and the state of public feeling would render trials by jury ineffective, that the guilty would not be prosecuted or punished, and that military trials are therefore necessary, are treated with scant respect. Ample relief is afforded by statutory provisions for a change of venue. It is not the function of one department to take the law into its own hands to supply the defects of the others and usurp their functions. This is not even an argument from necessity, but from convenience only. ${ }^{62}$ "Necessity" is the excuse invariably given for lynching and for mob law itself, the excuse of the miners for seeking by violence to enforce what they conceive to be their rights. If the civil magistrates and officers are intimidated, or in sympathy with the rioters, they may be removed, as was actually done by the civil courts in Butte. To open the courts is part of the duty devolving upon the military, and no closure by them can be recognized. The attempt to. try and punish offenders in Butte during the month of September by military courts was, therefore, abortive, a solemn and pompous farce. All their decisions are wiped out, and the penalties and punishments inflicted must be remitted as far as possible.

It is unfortunate that the military arm of the government must be used in these labor disputes, but when it is so used great precautions should be observed to avoid all appearance of arbitrary, illegal and oppressive action. It is to be hoped that the authorities will keep in view not only the importance of restoring peace, but also the importance of restoring peace with justice, and without depriving the humblest citizen of his confidence in the law and the lawful government. It is necessary to look to the future as well as to the apparent necessities and needs of the moment, and to the possible after-effects of stamping out disorder by the iron heel of martial law.

The laborers and workers of this country may come to believe that in the matter of the use of the military they are being discriminated against and that military power is being arbitrarily used as a tool in the interest of capital but is never exercised to

\footnotetext{
${ }^{62}$ By W. Va. Bill of Rights "any departure therefrom under the plea of necessity or any other plea, is subversive of good government, and tends to anarchy and despotism."
} 
protect the interests of the workers. ${ }^{63}$ It behooves those who must yield this dangerous but necessary force to inform themselves of the limits on their authority and to remember that their function is to preserve and enforce the law, not to supersede it, and that in general they are limited by what under the laws peace officers may do.

From a practical as well as a theoretical point of view, necessity never requires that the constitution be suspended and set aside or that the citizens be subjected to arbitrary military orders. Such claims are not only unfounded in law but also unwarranted on grounds of expediency. Experience proves that officious intermeddling of the military, however benevolent the motive, is not an unalloyed blessing. Lawful authority is adequate to meet any situation that may arise.

State statutes often purport to prescribe the occasions on which martial law or a "state of insurrection and rebellion" (whatever the consequences of that are) may be declared by the governor. In some states there are statutes asserting that members of the militia shall not be liable, civilly or criminally, for acts done while in active service, and that they shall not be prosecuted therefor in any court; also that military officers may exercise their discretion and be the sole judge as to what means are necessary to restore peace. These statutes are for the most part hasty and ill-considered attempts at legislation, apparently drawn up by those who have a peculiar eagerness to turn over absolute authority to an irresponsible military dictatorship, without any attempt to make a proper adjustment of the use of force to the safeguards of constitutional liberty. These statutes are no doubt largely unconstitutional, as a deprivation of the fundamental rights of the citizen under both the state and federal constitutions.

It might be supposed that the legal principles governing the use of the military in this country would be thoroughly established. In fact hardly any subject is so buried in darkness and misapprehension. The law is in a dangerous and disgraceful condition, misleading to the military, and fraught with peril to the community and to the citizen. In view of the importance of these questions, testing as they do the liberty of the individual citizen on the one hand, and the supreme power of government and social self-preservation on the other, and in view of the sud-

${ }^{e 3}$ The United States Commission on Industrial Relations is now making an elaborate investigation of this whole subject in all its phases. 
den and dramatic crises in which they arise, demanding instant decision, it is not a little strange that they have thus far received so little thoughtful attention. Some military code or system should be worked out under which the citizen will be protected in his rights, the community in its peace and safety, and the soldier in knowing the extent of his authority. It will require much study and labor on the part of some one to formulate such a code, which may be adopted by the various states, by which the duties and powers of the national guard may be properly defined, and by which necessary measures for the public safety may be reconciled with constitutional liberty.

Henry Winthrop Ballantine.

UNIVERSITY OF WISCONSIN. 